\title{
Antimicrobial Activity of Lactic Acid Bacteria from Bamboo Shoot Pickles Fermented at $15{ }^{\circ} \mathrm{C}$
}

\author{
LAKSMI HARTAYANIE*, LINDAYANI, AND MONIKA PALUPI MURNIATI \\ UNIKA Soegijapranata, Jalan Pawiyatan Luhur IV/1, Semarang 50234, Indonesia
}

\begin{abstract}
Lactic Acid Bacteria (LAB) produces natural antimicrobial compounds that can inhibit and prevent the growth of spoilage bacteria. LAB can be isolated from fermented food such as pickles, which ferment at cool temperature. The objectives of this research were to isolate and to obtain LAB from yellow Betung bamboo (Dendrocalamus asper) shoots pickles that has antimicrobial activity against Escherichia coli and Staphylococcus aureus. It was made by submerging yellow bamboo shoots in $2.5 \%$ brine solution and keeping them in sealed container, then fermenting them at cool temperature $\left(15^{\circ} \mathrm{C}\right)$ for 10 days. LAB was isolated using MRS agar and identified based on their morphological, physiological and biochemical characteristics. The result showed that LAB isolates identified as Lactobacilli and had antimicrobial activity against Escherichia coli and Staphylococcus aureus. All Lactobacilli (21 isolates) isolated from fermentation at $15{ }^{\circ} \mathrm{C}$ were homofementative.
\end{abstract}

Key words: antimicrobial activity, bamboo shoots pickles, fermentation temperature, lactic acid bacteria

Bakteri asam laktat (BAL) menghasilkan senyawa antimikroba sehingga dapat menghambat dan mencegah pertumbuhan bakteri pembusuk. BAL dapat diisolasi dari makanan fermentasi seperti acar yang difermentasi suhu dingin. Tujuan penelitian ini adalah mengisolasi dan mendapatkan isolat BAL dari acar rebung yang mempunyai aktivitas penghambatan terhadap Escherichia coli dan Staphylococcus aureus. Rebung difermentasi dalam larutan garam $2.5 \%$ dalam wadah tertutup pada suhu $15^{\circ} \mathrm{C}$ selama 10 hari. BAL yang berhasil diiolasi diidentifikasi sebagai Lactobacillus yang homofermentatif dan mempunyai aktivitas antimikroba terhadap Escherichia coli dan Staphylococcus aureus.

Kata kunci: Acar rebung, Aktivitas antimikroba, bakteri asam laktat, suhu fermentasi

Utilization of bacteria beneficial to human health in the food world is now more advanced. Basically the bacteria can be divided into two groups, the beneficial bacteria and harmful bacteria. Lactic acid bacteria (LAB) belong to the beneficial bacteria for producing lactic acid. $L A B$ has made a great contribution in the development of fermented foods, particularly in foods that contain probiotics (Lindayani and Hartayanie 2013). LAB includes microorganisms of the genera Lactobacillus, Leuconostoc, Streptococcus, and Pediococcus.

The lactic acid produced from the metabolic activity of LAB causes the condition of raw materials (food) becomes acidic. This is particularly advantageous, given the low $\mathrm{pH}$ condition that inhibits the damage caused by other microbes in almost all food (food spoilage microbes). According to Josephsen and Jespersen in Hui et al. (2004), LAB produces metabolites that function as antimicrobial compounds including organic acids (lactic acid and acetic acid), bacteriocins, hydrogen peroxide, diacetyl, and $\mathrm{CO}_{2}$.

*Corresponding author; Phone: +62-24-8441555, Email:laksmi@unika.ac.id
Bamboo shoots are the young shoots of bamboo plants that appear at the bottom surface of the clump. The young shoots of bamboo can be consumed, thus classified as vegetable. Bamboo shoots that can be consumed are usually derived from species Dendrocalamus asper (yellow Betung), Gigantochloa verticillata, Dendrocalamus litiforus (yellow bamboo), and Bambusa aldhami (green bamboo) (Andoko 2003). Raw bamboo shoots have water content of about $90 \%$ net weight (Rai 2007).

Bamboo shoots fermentation process takes place spontaneously. The fermentation is done by adding brine. Brine prevents the liquid contained in bamboo shoots drawn out through the process of osmosis and also serves to inhibit the growth of pathogenic bacteria, so only the lactic acid bacteria are expected to grow. The final result of fermentation process is often called pickled bamboo shoots.

The aim of this study is to isolate and identify the lactic acid bacteria of pickled yellow Betung bamboo (D. asper) shoots fermented at colder temperatures (15 ${ }^{\circ} \mathrm{C}$ ) and $2.5 \%$ salt content, and to investigate the antimicrobial activity of the lactic acid bacteria. 


\section{MATERIALS AND METHODS}

The Pickling of Bamboo Shoots. Two hundred fifty grams yellow Betung bamboo shoots was washed, cut and put in a jar, then $2.5 \%(\mathrm{w} / \mathrm{v})$ saline solution was added and then the jar was sealed and kept in the incubator. The fermentation process lasted for $10 \mathrm{~d}$ at a cold temperature $\left(15^{\circ} \mathrm{C}\right)$ (Rahayu 2003 modified).

Isolation and Purification of Lactic Acid Bacteria. Twenty five $\mathrm{mL}$ liquid from pickled bamboo shoots was diluted with $225 \mathrm{~mL}$ sterile $0.1 \%$ peptone water $\left(10^{-1} \times\right.$ concentration $)$. The dilution process was conducted serially until the liquid was diluted down to $10^{-7} \times$ the original concentration. $0.1 \mathrm{ml}$ sample was taken from each dilution and inoculated into MRS agar medium containing $1 \% \mathrm{CaCO}_{3}$ by spreading and incubated at $37{ }^{\circ} \mathrm{C}$ for $48 \mathrm{~h}$. Colonies that formed clear zone was further purified using the same methods and media (Yuliana and Dizon 2011).

Morphological Identification. Lactic acid bacterial isolates were identified by microscopic observation based on the shape of the bacteria using Gram staining and spore staining (Sneath et al. 1984).

Motility Test. Isolates were taken aseptically using a needle and inoculated by puncturing into motility medium (MRS with $0.7 \%$ agar). Incubation was performed at $37^{\circ} \mathrm{C}$ for $48 \mathrm{~h}$. Non-motile isolates would have grown only around the puncture, while motile isolates would have spread farther (Rahayu and Margino 1997).

Catalase Test. One loop of isolate was smeared onto an object glass that had been cleaned with alcohol. Then, drops of $3 \% \mathrm{H}_{2} \mathrm{O}_{2}$ solution were added. The formation of gas bubbles indicated that isolates were catalase positive and vice versa (Gawad et al.2010).

Gas Production Test. Fifty $\mu \mathrm{L}$ lactic acid bacteria inoculum was used to inoculate $5 \mathrm{~mL}$ MRS broth with $6.5 \%$ and $18 \% \mathrm{NaCl}$ concentrations. Each medium that had been inoculated with lactic acid bacteria was subsequently incubated at $37^{\circ} \mathrm{C}$ for $48 \mathrm{~h}$. Observations of growth were done by measuring the absorbance value at $700 \mathrm{~nm}$ wavelength at 24 and $48 \mathrm{~h}$ (Rahayu and Margino 1997).

Growth at various pH (4.4 and 9.6). $50 \mu \mathrm{L}$ lactic acid bacteria culture was inoculated into $5 \mathrm{~mL}$ MRS broth media pH 4.4 and $\mathrm{pH} 9.6$ and then incubated at 37 ${ }^{\circ} \mathrm{C}$ for $48 \mathrm{~h}$. Observation of growth were done by measuring the absorbance value at $700 \mathrm{~nm}$ wavelength at 24 and $48 \mathrm{~h}$ (Rahayu and Margino 1997).

Growth at various temperatures $\left(10{ }^{\circ} \mathrm{C}, 45^{\circ} \mathrm{C}\right.$, and $50^{\circ} \mathrm{C}$ ). $50 \mu \mathrm{L}$ lactic acid bacterial culture was used to inoculate $5 \mathrm{~mL}$ MRS broth media. Then, each media that had been inoculated was incubated at either $10{ }^{\circ} \mathrm{C}, 45^{\circ} \mathrm{C}$ or $50^{\circ} \mathrm{C}$ for $48 \mathrm{~h}$. Observations of growth were done by measuring the absorbance value at 700 $\mathrm{nm}$ wavelength, 24 and $48 \mathrm{~h}$ after inoculation (Rahayu and Margino 1997).

Growth on Different $\mathrm{NaCl}$ Levels $(6.5 \%$ and 18\%). $50 \mu \mathrm{L}$ lactic acid bacterial culture was used to inoculate $5 \mathrm{~mL}$ MRS broth media with different $\mathrm{NaCl}$ concentrations $(6.5 \%$ and $18 \%)$. Each medium that had been inoculated with lactic acid bacteria was subsequently incubated at $37^{\circ} \mathrm{C}$ for $48 \mathrm{~h}$. Observations of growth were done by measuring the absorbance value at $700 \mathrm{~nm}$ wavelength, 24 and $48 \mathrm{~h}$ after inoculation (Rahayu and Margino, 1997).

Antimicrobial Activity. Measurement of antibacterial activity was conducted using wells (well assay). Lactic acid bacterial culture was diluted in $0.85 \% \mathrm{NaCl}$ solution with turbidity level adjusted according to McFarland standard number 5 (IniguezPalomares et al.2007). $0.1 \mathrm{~mL}$ of the diluted culture was taken and added to $10 \mathrm{~mL}$ liquid MRS medium (Khunajakr et al. 2008) for further $24 \mathrm{~h}$ incubation at 37 ${ }^{\circ} \mathrm{C}$. Pathogenic bacteria was grown for $24 \mathrm{~h}$ then diluted in $0.85 \% \mathrm{NaCl}$ solution with turbidity level adjusted to McFarland standard number 3 (IniguezPalomares et al.2007). $10 \mathrm{~mL}$ of the diluted pathogenic bacterial culture was added to $10 \mathrm{~mL}$ of NA medium and poured into a petri dish and let to solidity. Then, a hole with $5 \mathrm{~mm}$ diameter was made and filled with 50 $\mathrm{mL}$ of lactic acid bacterial culture that had been grown in MRS broth media. Subsequently, the petri dish was stored at $4{ }^{\circ} \mathrm{C}$ for $3 \mathrm{~h}$ to make sure the bacteria had diffused into the media. After $3 \mathrm{~h}$, the petri dish was moved to $37{ }^{\circ} \mathrm{C}$ and further incubated for $24 \mathrm{~h}$. Clear zone formed was measured using a caliper.

\section{RESULTS}

Isolation and Identification of Lactic Acid Bacteria. Pickled yellow betung bamboo (D. asper) shoots, was used as source of microbial isolation using MRS containing $1 \% \mathrm{CaCO}_{3}$ and $10 \mathrm{ppm}$ Na-Azide as selective medium. Na-Azide serves to inhibit aerobic microbial growth by binding to the free $\mathrm{O}_{2}$. Pure culture was obtained by separating the colonies from one another. Twenty one isolates (Fig 1), which gave clear zone, were found.

All 21 isolates were subsequently identified based on their morphological and physiological characters. The identification was done by testing the 


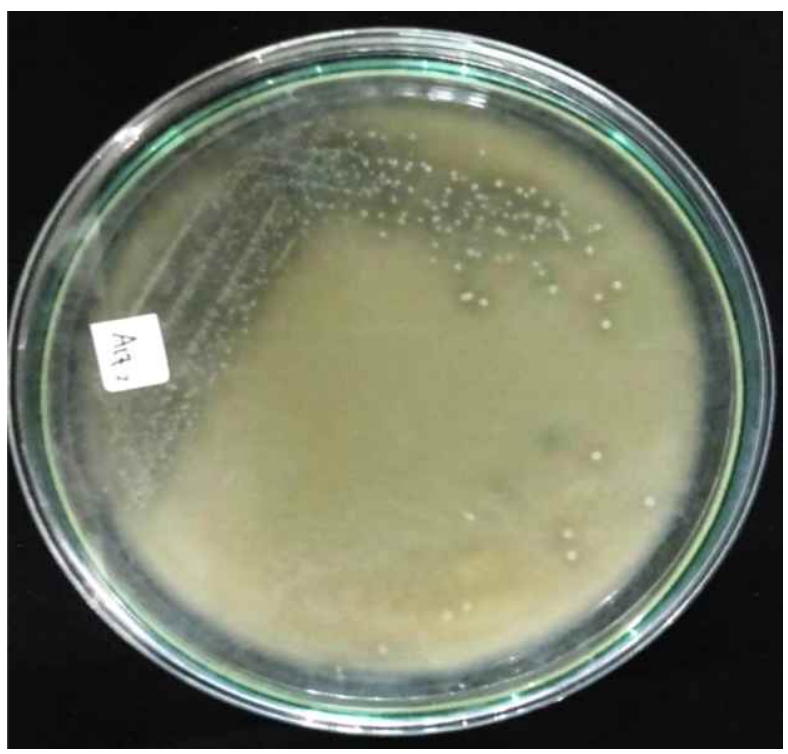

Fig 1 Colonies of lactic acid bacteria form a clear zone (isolate A17).

morphological character by gram and spore staining, catalase test, motility test and gas production (Table 1).

All isolates were identified more specifically to determine the genus of the lactic acid bacteria. The identification was done by testing the ability to grow at different temperatures $\left(10{ }^{\circ} \mathrm{C}, 45{ }^{\circ} \mathrm{C}\right.$, and $\left.50{ }^{\circ} \mathrm{C}\right)$, different concentrations of $\mathrm{NaCl}(6.5 \%$ and $18 \%)$, and at different $\mathrm{pH}$ (4.4 and 9.6). It was known that all isolates could grow at $6.5 \% \mathrm{NaCl}, \mathrm{pH} 4.4$ and $45^{\circ} \mathrm{C}$. Most isolates can grow at $10^{\circ} \mathrm{C}$ and a small percentage of isolates can grow at $50{ }^{\circ} \mathrm{C}$. However, none of these isolates could survive at $\mathrm{pH} 9.6$ and $18 \% \mathrm{NaCl}$. These results show that all the tested isolates belong to the genus Lactobacillus (Table 2).

Antimicrobial Activity of Lactic Acid Bacteria. Lactic acid bacteria isolates were tested for antimicrobial activity. Antimicrobial activity test was conducted using agar diffusion method and using two bacterial pathogens, Escherichia coli strain ATCC 252 922 (Gram-negative) and Staphylococcus aureus strain ATCC 252923 (Gram-positive) (Fig 2).

Isolate A12 had the highest antimicrobial capability against $S$. aureus with inhibition zone diameter of $11.07 \mathrm{~mm}$, while isolate A20 had the highest antimicrobial capability against Escherichia coli with inhibition zone diameter of $10.93 \mathrm{~mm}$ (Fig 3). These results indicate that both isolates have very strong antimicrobial ability.

Some isolates (A1, A13, A19, and A23) showed no inhibition against S.aureus dan E.coli. The isolates which had antimicrobial activity showed larger clear zone against $S$. aureus than $E$. coli except A20, A24, and A31 (Table 3).

\section{DISCUSSION}

In this research, shoots of yellow Betung bamboo (D. asper) was used for fermentation. The fermentation process was carried out for $9 \mathrm{~d}$ at $15{ }^{\circ} \mathrm{C}$ and was completed when the $\mathrm{pH}$ decreased to below 4.5, because lactic acid bacteria will stop growing at lower $\mathrm{pH}$ (Rehm and Reed 1996). Fermentation performed at low temperatures takes longer than the fermentation process in general. The lower temperature can lead to inhibition of the growth of lactic acid bacteria, so that limited amount of lactic acid was produced due to slower fermentation process. Clear zone around the colony arised due to the reaction between the acid produced by bacteria with $\mathrm{CaCO}_{3}$ in media resulting soluble $\mathrm{Ca}$-lactate in the media and seen as a clear zone.

Table 1 showed that all isolates have characteristics similar to the common characteristics of lactic acid bacteria. They were gram-positive, rod-shaped or cocci, catalase negative, non-spore-forming, nonmotile and produced acids (mainly lactic acid and acetate) (Ghiasi 2011; Aly et al. 2006). All isolates were identified as Lacotobacillus (Table 2). Lactobacillus growth characteristics include capability to grow at suitable temperatures $10{ }^{\circ} \mathrm{C}-50{ }^{\circ} \mathrm{C}, 6.5 \%$ $\mathrm{NaCl}$ and $\mathrm{pH} 4.4$, but unable to grow at $18 \% \mathrm{NaCl}$ and pH 9.6 (Rahayu and Margino 1997). This result is quite different from the research conducted by the Tamang and Sarkar (1996) in Choudhury et al, (2012), whostated that Lactobacillus were not the only LAB found in bamboo shoots fermented at room temperature, but also Pediococcus and Leuconostoc. 
Table 1 Identification of lactic acid bacteria in pickled betung bamboo shoots (Dendrocalamus asper)

\begin{tabular}{|c|c|c|c|c|c|c|c|c|}
\hline Isolates & $\begin{array}{l}\text { Clear } \\
\text { zone }\end{array}$ & $\begin{array}{l}\text { Gram } \\
\text { staining }\end{array}$ & $\begin{array}{c}\text { Spore } \\
\text { Staining }\end{array}$ & $\begin{array}{l}\text { Bacteria } \\
\text { Form }\end{array}$ & Catalase & Motility & $\begin{array}{c}\text { Gas } \\
\text { production }\end{array}$ & Result \\
\hline A 1 & + & + & - & $\mathrm{b}$ & - & - & + & B \\
\hline A 2 & + & + & - & $\mathrm{b}$ & - & - & + & B \\
\hline A3 & + & + & - & $\mathrm{b}$ & - & - & + & B \\
\hline A11 & + & + & - & $\mathrm{b}$ & - & - & + & B \\
\hline A 12 & + & + & - & $\mathrm{b}$ & - & - & + & B \\
\hline A13 & + & + & - & $\mathrm{b}$ & - & - & + & B \\
\hline A15 & + & + & - & $\mathrm{b}$ & - & - & + & B \\
\hline A16 & + & + & - & $\mathrm{b}$ & - & - & + & B \\
\hline A17 & + & + & - & $\mathrm{b}$ & - & - & + & B \\
\hline A 18 & + & + & - & $\mathrm{b}$ & - & - & + & B \\
\hline A19 & + & + & - & $\mathrm{b}$ & - & - & + & B \\
\hline 420 & + & + & - & $\mathrm{b}$ & - & - & + & B \\
\hline $\mathrm{A} 23$ & + & + & - & $\mathrm{b}$ & - & - & + & B \\
\hline A24 & + & + & - & $\mathrm{b}$ & - & - & + & B \\
\hline A27 & + & + & - & $\mathrm{b}$ & - & - & + & B \\
\hline A 31 & + & + & - & $\mathrm{b}$ & - & - & + & B \\
\hline A 32 & + & + & - & $\mathrm{b}$ & - & - & + & B \\
\hline A 33 & + & + & - & $\mathrm{b}$ & - & - & + & B \\
\hline A34 & + & + & - & $\mathrm{b}$ & - & - & + & B \\
\hline A 43 & + & + & - & $\mathrm{b}$ & - & - & + & B \\
\hline A44 & + & + & - & $\mathrm{b}$ & - & - & + & B \\
\hline
\end{tabular}

The bacterial form of basil: "-" = negative / no form: "++" = Positive / form: "B" = the lactic acid bacteria.

This indicates that the fermentation temperature has an influence on the growth of LAB.

E. coli strain ATCC 252922 (Gram-negative) and S. aureus strain ATCC 252923 (Gram-positive) were used for antimicrobial test because both bacteria were the most common pathogens attacking human. $S$. aureus is a gram-positive that lives as a saprophyte in the membrane channels of the human body, the surface of the skin, sweat glands, and the intestinal tract, while $E$. coli is a gram-negative commonly found in the human colon as normal flora. All isolates have antimicrobial activity or inhibitory ability against pathogens as indicated by the appearance of clear zone around the holes was filled with isolate (Fig 2).

This is due to the differences in the composition and structure of the cell wall of Gram-positive bacteria (S. aureus) and Gram-negative bacteria (E.coli). Cell wall structure of Gram-positive bacteria is more simple, single-layered with a low lipid content (1-4\%), to facilitate the bioactive material transport into the cell. On the other hand, Gram negative bacteria have more complex structure, consisting of a three-layered 
Table 2 Results identification of lactic acid bacteria growth bacteria based capabilities at various ph, temperature, and

\begin{tabular}{|c|c|c|c|c|c|c|c|c|}
\hline \multirow{2}{*}{ Isolates } & \multicolumn{2}{|c|}{$\mathrm{pH}$} & \multicolumn{3}{|c|}{ Temperature $\left({ }^{\circ} \mathrm{C}\right)$} & \multicolumn{2}{|c|}{$\mathrm{NaCl}(\%)$} & \multirow{2}{*}{ Genus } \\
\hline & 4.4 & 9.6 & 10 & 45 & 50 & 6.5 & 18 & \\
\hline A 1 & + & - & - & + & + & + & - & Lactobacillus \\
\hline A 2 & + & - & + & + & - & + & - & Lactobacillus \\
\hline A3 & + & - & + & + & - & + & - & Lactobacillus \\
\hline A11 & + & - & + & - & - & + & - & Lactobacillus \\
\hline A12 & + & - & + & + & - & + & - & Lactobacillus \\
\hline A13 & + & - & + & + & - & + & - & Lactobacillus \\
\hline A15 & + & - & - & + & + & + & - & Lactobacillus \\
\hline A16 & + & - & + & + & - & + & - & Lactobacillus \\
\hline A17 & + & - & + & + & - & + & - & Lactobacillus \\
\hline A18 & + & - & - & + & + & + & - & Lactobacillus \\
\hline A19 & + & - & + & + & - & + & - & Lactobacillus \\
\hline 420 & + & - & + & + & - & + & - & Lactobacillus \\
\hline A23 & + & - & + & + & - & + & - & Lactobacillus \\
\hline A24 & + & - & + & + & - & + & - & Lactobacillus \\
\hline A27 & + & - & + & + & - & + & - & Lactobacillus \\
\hline A 31 & + & - & + & + & - & + & - & Lactobacillus \\
\hline A 32 & + & - & + & + & - & + & - & Lactobacillus \\
\hline A33 & + & - & + & + & - & + & - & Lactobacillus \\
\hline A34 & + & - & + & + & - & + & - & Lactobacillus \\
\hline $\mathrm{A} 43$ & + & - & + & + & - & + & - & La ctobacillus \\
\hline A44 & + & - & + & + & - & + & - & Lactobacillus \\
\hline
\end{tabular}

$+=$ isolates grow

- = Isolates did not grow

outer layer lipoprotein, lipopolysaccharide middle layer which acts as a barrier to the entry of antibacterial compounds, and peptidoglycan inner layer with a high lipid content (11-12\%) (McKane and Kandel 1996).

The ability of lactic acid bacteria in inhibiting the growth of pathogenic bacteria was due to the antimicrobial components produced by lactic acid bacteria, one of which is lactic acid. The lactic acid caused a decrease in $\mathrm{pH}$ so that the growth of Grampositive $(+)$ and Gram negative $(-)$ bacteria which cannot stand low $\mathrm{pH}$ would be inhibited. Although gram-negative bacteria have lipopolysaccharide layer, the lactic acid can still inhibit it. This is because lactic acid is a water-soluble molecule that can permeate into the outer membrane. Lipopolysaccharide layer was damaged by lactic acid so that other antimicrobials such as diacetyl, bacteriocins and hydrogen peroxide can enter the cells (Alokomi et al. 2000 in Afriani 2012). From this study, it can be concluded that twenty one isolates of lactic acid bacteria found in pickled 


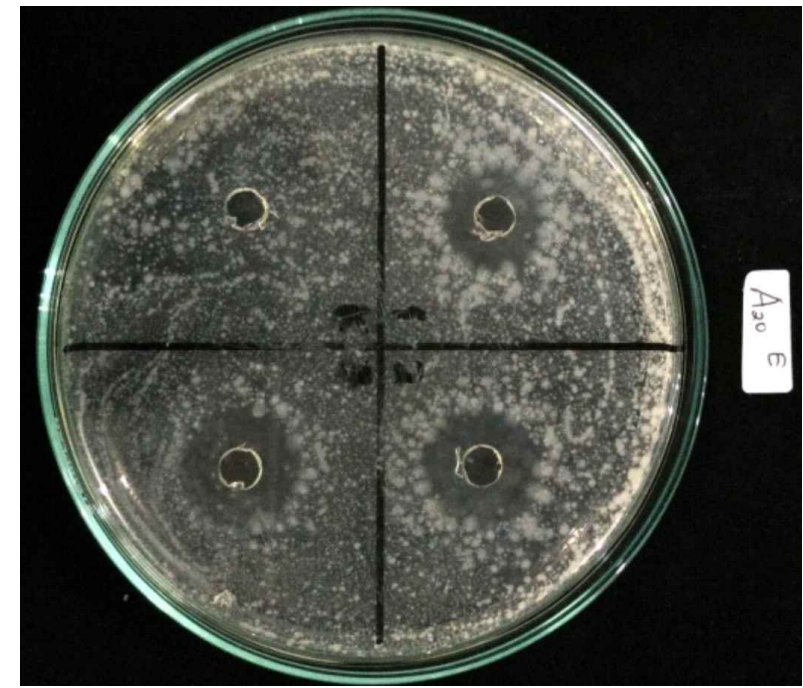

A

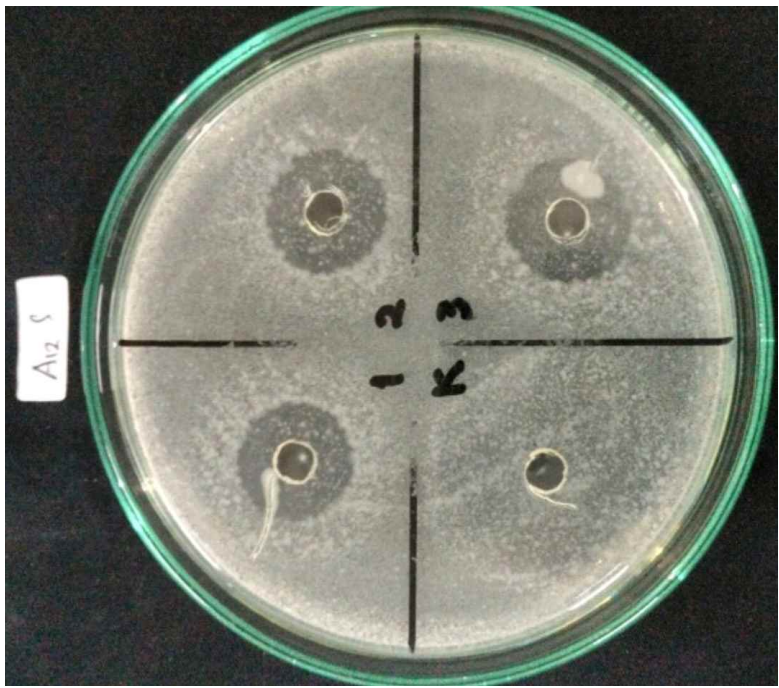

B

Fig 2 The test results on the antimicrobial activity of isolate A20 pathogenic bacteria Escherichia coli (a); A12 on Staphylococcus aureus (b). k: control (medium without the addition of isolates; 1: isolates test (I repeat); 2: isolates test (replications II); 3: isolates test (replications III).

Table 3 Antimicrobial activity

\begin{tabular}{ccc}
\hline \multirow{2}{*}{ Isolates code } & \multicolumn{2}{c}{ Diameter clear zone $(\mathrm{mm})$} \\
\cline { 2 - 3 } A. & S.ureus & E.coli \\
\hline A2 & 0.00 & 0.00 \\
A3 & 9.77 & 9.03 \\
A11 & 6.67 & 10.5 \\
A12 & 10.67 & 10.53 \\
A13 & 11.07 & 7.97 \\
A15 & 0.00 & 0.00 \\
A16 & 10.00 & 8.20 \\
A17 & 0.00 & 9.17 \\
A18 & 8.47 & 0.00 \\
A19 & 0.00 & 7.90 \\
A20 & 9.70 & 0.00 \\
A23 & 0.00 & 0.00 \\
A24 & 7.23 & 8.70 \\
A27 & 7.60 & 7.27 \\
A31 & 6.20 & 9.57 \\
A32 & 10.27 & 7.47 \\
A33 & 6.90 & 0.00 \\
A34 & 14.53 & 9.30 \\
A43 & 10.70 & 9.67 \\
A44 & 427 & 400 \\
\hline
\end{tabular}

bamboo shoots fermented at $15{ }^{\circ} \mathrm{C}$ were identified as Lactobacillus. Seventeen isolates had antimicrobial activity that can inhibit the growth of pathogenic bacteria $E$. coli and $S$. aureus. Isolate A34 has the highest antimicrobial activity against $S$. aureus with inhibition zone diameter $14.53 \mathrm{~mm}$ and isolate $\mathrm{A} 20 \mathrm{had}$ the highest antimicrobial ability against $E$. coli with inhibition zone diameter $10.93 \mathrm{~mm}$

\section{ACKNOWLEDGMENTS}

This research can take place with financial support from the Directorate General of Higher Education and laboratory facilities of the Faculty of Agricultural 
Technology-Soegijapranata Catholic University. Thanks for the help (Ardelia, Amelia, Cynthia, Agatha, and Lorentia) and the support of all parties involved.

\section{REFERENCES}

Afriani. 2012. Kualitas dan aktivitas antimikroba produk dadih susu sapi pada penyimpanan suhu rendah. Agrinak 2(1):11-16.

Aly S, Cheik AT, Imael HN, Alfred TS. 2006. Bacteriocins and lactic acid bacteria-A Minireview. Afr J Biotechnol. 5(9):678-683.

Andoko A. 2003. Budidaya Bambu Rebung. Kanisius, Yogyakarta.

Battcock M, Azam-Ali S. 1998. Fermented Fruits and Vegetables, A Global Perspective. FAO Agricultural Services Bulletin No. 134.

Choudhury D, Sahu JK, Sharma GD. 2012. Bamboo shoot: microbiology, biochemistry and technology of fermentation-A Review. Indian Journal of Traditional Knowledge 11(2):242-249.

de Vuyst L, Vandamme EJ. 1994. Bacteriocins of Latic Acid Bacteria. Blackie Academic \& Professional.

Gawad AE, Fatah AE, Rubayyi A. 2010. Identification and characterization of dominant lactic acid bacteria isolated from traditional rayeb milk in Egypt. Journal of American Science. 6(10): 728-735.

Ghiasi F. 2011. Predominant lactic acid bacteria isolated from the intestines of silver carp in low water temperature. Afr J Biotechnol. 10(59):12747-12751.
Iniguez-Palomares $\mathrm{C}$, Perez-Morales $\mathrm{R}$, Acedo-Felix E. 2007. Evaluation of probiotic properties in Lactobacillus isolated from small intestine of piglets. Revista Latino Americana de Microbiologi 49(3-4):46-54.

Khunajakr N, Wongwicharn A, Moonmangmee D. 2008. Screening and identification of lactic acid bacteria producing antimicrobial compounds from pig gastrointestinal tracts. Journal of KMITL Science Technology. 8(1):8-17.

Lindayani, Hartayanie L. 2013. The Mapping of Lactid Acid Bacteria from Fermentation of Local Foods (Semarang): Tempoyak, Mandai and Yellow Bamboo Shoot Pickles. Oral Presentation in The $4^{\text {th }}$ International 1 Conference of Indonesian Society Lactic Acid Bacteria (ISLAB). Yogyakarta, 25 $-26^{\text {th }}$ January 2013.

Mc Kane L, Kandel J. 1996. Microbiology: Essentials and Applications. Mc Graw Hill.

Rahayu, ES. 2003. Lactic acid bacteria in fermented foods of Indonesian origin. Agritech. 23(2) : 75-84.

Rehm HJ, Reed G. 1996. Biotechnology $2^{\text {nd }}$ Edition Volume 6: Products of primary metabolism. VCH verlagsgesellschaft mbH, Weinheim. Germany.

Sneath PHA, Mair NS, Sharpe ME and Holt JG. 1984. Bergeys manual of systematic bacteriology. Vol 2. Williams \&Wilkins. Baltimore.

Yuliana N, Dizon EI. 2011. Phenotypic Identification of lactic acid bacteria isolated from Tempoyak (fermented durian) made in the Philippines. Int J Biol. 3(2): 145151. doi:10.5539/ijb.v3n2p145. 